\title{
H5N2 Avian Influenza Virus
}

National Cancer Institute

\section{Source}

National Cancer Institute. H5N2 Avian Influenza Virus. NCI Thesaurus. Code C121658.

A highly pathogenic subtype of avian influenza A virus. This virus was responsible for a

large outbreak of avian influenza in commercial flocks, starting in late 2014 and continuing into 2015. 